\title{
Kajian Sistematik: Efek Gen Multi Drug Resistance-1 pada Farmakokinetik Klopidogrel
}

\author{
A Systematic Review: Impact of Multi Drug Resistance-1 Gene \\ on Clopidogrel Pharmacokinetics \\ Rasmaya Niruri $^{1^{*}}$, Rini Noviyani ${ }^{2,4}$, Indah Mei Rahajeng ${ }^{3}$ \\ ${ }^{I}$ Program Studi Farmasi, FMIPA, Universitas Sebelas Maret, Indonesia \\ ${ }^{2}$ Program Studi Farmasi, FMIPA, Universitas Udayana, Indonesia \\ ${ }^{3}$ Program Studi Ilmu Keperawatan, Fakultas Kedokteran, Universitas Udayana, Indonesia \\ ${ }^{4}$ Doctor of Phylosophy Program in HTA (International Program), Faculty of Pharmacy, Mahidol \\ University, Thailand \\ *E-mail: rasmaya@staff.uns.ac.id
}

Diterima: 15 Oktober 2018

Direvisi: 26 Januari 2019

Disetujui: 16 Februari 2019

\begin{abstract}
Abstrak
Polimorfisme gen Multi Drug Resistance-1 (MDR-1), yang merupakan gen penyandi P-glycoprotein, dapat mempengaruhi absorpsi pada saluran cerna. Kajian sistematik ini bertujuan untuk mengidentifikasi efek dari gen MDR-1 varian 3435 pada farmakokinetik klopidogrel. Literatur kajian diperoleh dari database MEDLINE, Science Direct, Scopus, Clinical Key, ProQuest dan Google Scholar. Dilakukan critical review dan analisis artikel riset yang diperoleh untuk mencapai tujuan kajian ini. Hasil kajian menunjukkan bahwa pada pasien dengan penyakit kardiovaskular, kadar puncak $\left(\mathrm{C}_{\text {maks }}\right)$ dan total daerah dibawah kurva/total Area Under Curve (AUC) klopidogrel dan/atau metabolit aktifnya adalah lebih rendah secara signifikan pada subjek dengan 3435TT dibandingkan pada 3435CC. Namun, varian Gen $M D R-1$ tidak berkorelasi secara signifikan pada konsentrasi plasma subjek sehat. Profil farmakokinetik klopidogrel menunjukkan perbedaan pada $M D R-1$ varian 3435 dan status kesehatan yang berbeda.
\end{abstract}

Kata kunci: MDR-1; Varian 3435; Farmakokinetik klopidogrel

\begin{abstract}
Multi Drug Resistance-1 (MDR-1) gene polymorphisms encoding for P-glycoprotein can affect clopidogrel intestinal absorption. This systematic review aim to identify the impact of MDR-1 gene 3435 variants on clopidogrel pharmacokinetics. Literature review were retrieved from MEDLINE, Science Direct, Scopus, Clinical Key, ProQuest and Google Scholar databases. The articles are critically reviewed and analyzed to answer this systematic review's aim. The result showed that, in patients with cardiovascular disease, the peak plasma concentration $\left(C_{\max }\right)$ and the total area under the plasma concentration-time curve (AUC) of clopidogrel and its active metabolites were lower in 3435TT compared to 3435CC. Nevertheless, the variants of MDR-1 gene were not significantly correlated to the plasma concentration in healthy subjects. Clopidogrel pharmacokinetic profile varied widely between MDR-1 3435 variants and subjects.
\end{abstract}

Keywords: MDR-1; 3435 variant; Clopidogrel pharmacokinetic 


\section{PENDAHULUAN}

Gen Multi Drug Resistance-1(MDR-1) varian 3435 ditemukan dengan frekuensi tinggi pada populasi asia. ${ }^{1}$ Varian tersebut berkaitan secara signifikan pada major adverse cardiovascular outcome (MACE). ${ }^{2}$ $P$-glycoprotein (P-gp), yang disandi oleh Gen MDR-1, adalah suatu adenosine triphosphate (ATP)-dependent-drug-efflux pump. P-gp atau MDR-1 transporter berperan penting dalam bioavailabitas xenobiotika. Adanya varian pada gen MDR1 dapat mempengaruhi tingkat ekspresi dan fungsi P-gp. ${ }^{1}$

Respon yang buruk (poor responsiveness) pada terapi clopidogrel berkaitan dengan genotip TT pada polimorfisme 3435 . Pasien yang mengalami agregasi platelet lebih dari $70 \%$ diklafikasikan kedalam poor responsiveness. ${ }^{3}$ Terdapatnya $\mathrm{T}$ allele carier pada 3435 tersebut juga merupakan faktor resiko terjadinya MACE pada pasien dengan loading dose klopidogrel $300 \mathrm{mg}^{2}$ Riset kajian sistematik ini bertujuan untuk mengidentifikasi efek dari Gen MDR-1 varian 3435 pada farmakokinetik klopidogrel.

\section{METODE}

Dilakukan kajian sistematik terhadap sejumlah artikel riset dari tahun 2006 yang ditelusuri, diseleksi, dan dilakukan penilaian terhadap kualitasnya. Seleksi dan penilaian kualitas artikel riset dilakukan oleh 2 (dua) reviewer. Jika terdapat perbedaan, maka dipecahkan dengan diskusi antara 2 reviewer. Ketika perbedaan tetap tidak dapat diselesaikan maka dilakukan konsultasi lebih lanjut dengan reviewer ketiga.

\section{Strategi pencarian dan seleksi artikel riset}

Pencarian secara komprehensif pada database MEDLINE, Science Direct, Scopus, Clinical Key, ProQuest, dan Google Scholar dilakukan untuk memperoleh literatur yang paling relevan dengan tujuan kajian ini. Keseluruhan kombinasi kata kunci yaitu (("platelet aggregation inhibitors") or ("clopidogrel")) and (("mdrl gene") or ("ABCB1")) and (("bioavailability") or ("pharmacokinetic") or ("pharmacokinetics")) diterapkan pada pencarian artikel riset pada database.

Artikel riset yang memenuhi kriteria inklusi akan dianalisis, yaitu fulltext studi observasional dan clinical trial yang original dimana subjeknya mendapatkan pemeriksaan genotip pada gen MDR-1 varian 3435 dan dilakukan evaluasi parameter farmakokinetik dari klopidogrel. Artikel yang memenuhi kriteria eksklusi akan dikeluarkan dan tidak dianalisis. Kriteria eksklusi pada kajian ini adalah: artikel riset yang tidak dalam Bahasa Inggris, adanya duplikasi artikel, artikel riset yang hanya diperoleh dalam bentuk abstrak atau dalam bentuk laporan, dan jika keseluruhan data pada fulltext tidak dapat diakses. Jika artikel merupakan duplikasi (terdapat lebih dari satu artikel dengan pengarang yang sama, judul, dan abstrak yang sama) namun dipublikasikan pada penerbit yang berbeda, maka akan dipilih artikel dengan tahun terbit lebih awal. Artikel riset yang potensial dan relevan akan di ekstrak berdasarkan judul dan abstrak, selanjutnya fulltext disaring berdasarkan kriteria kajian ini.

\section{Penilaian kualitas artikel riset dan sintesis data}

The Quality Assessment Tool for Observational Cohort and CrossSectional Studies dari the National Institutes of Health, National Heart, Lung, and Blood Institute digunakan untuk mengevaluasi kualitas dari artikel riset. $^{5}$ Pada penilaian kualitas metodologi, yang dimasud exposure adalah subjek (pada artikel riset yang dianalisis) yang telah dilakukan pemeriksaan genotip gen $M D R-1$ pada posisi 3435 dan outcome adalah hasil parameter farmakokinetik pada subjek dengan varian 3435. Data yang terekstrak akan dianalisis secara deskriptif. 


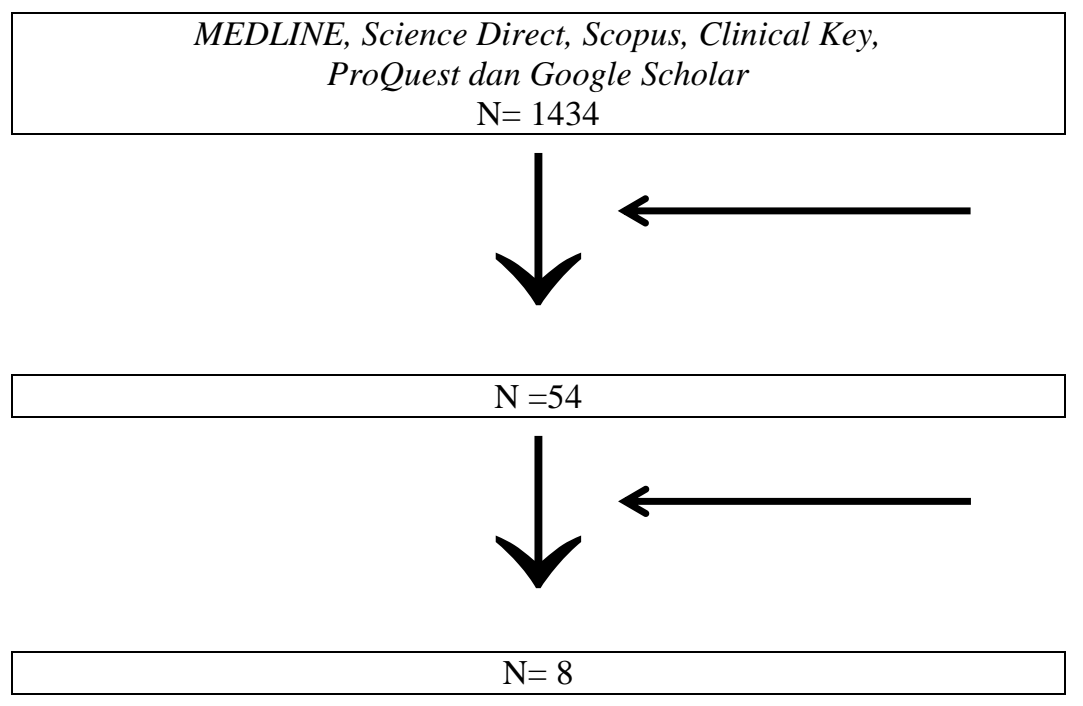

1380 dieksklusi karena tidak berbahasa Inggris, duplikasi, atau tidak relevan (berdasarkan judul dan abstrak)

46 dieksklusi karena tidak relevan (setelah membaca lebih lanjut pada fulltext) atau tidak bisa diakses keseluruhan data pada fulltext-nya

Gambar 1. Flow chart hasil seleksi riset artikel

\section{HASIL DAN PEMBAHASAN}

\section{Seleksi artikel}

Terdapat 1434 artikel yang dapat diakses judul dan abstraknya melalui enam database yang digunakan. Dari artikel tersebut, diperoleh 8 artikel riset yang memenuhi kriteria (Gambar 1, Tabel 1, dan Tabel 2) dan dilakukan penilaian kualitas metodologi.

Berdasarkan penilaian kualitas, terdapat setidaknya 1 kriteria yang tidak sesuai dengan tool criteria, sehingga mempengaruhi kualitas (Tabel 2 dan Tabel 3). Faktor yang berkontribusi membuat kualitas artikel lebih rendah adalah jumlah sampel yang relatif sedikit, jumlah persentase yang besar (>20\%) untuk partisipan yang tidak dapat diikuti hingga akhir penelitian (participants who loss to follow up), tidak adanya adjustment/pengukuran dari confounding variable yang potensial berpengaruh pada farmakokinetik klopidogrel, serta ketidakcukupan data pada baseline karakteristik subjek riset.

Hasil penilaian kualitas artikel pada kajian ini (Tabel 3) diperoleh 1 artikel dengan rating yang bagus, 6 artikel rating cukup, dan 1 artikel rating kurang.

Tabel 1. Area Under Curve pada subyek sehat dan pasien

\begin{tabular}{|c|c|c|c|c|}
\hline Subyek & $\begin{array}{c}\text { Dosis } \\
\text { Klopidrogel }\end{array}$ & Genotipe & $\begin{array}{c}\text { AUC dari klopidogrel } \\
\text { (ng/ml x jam) }\end{array}$ & $\begin{array}{c}\text { AUC darimetabolit aktifklopidogrel * } \\
(\text { ng/ml x jam) }\end{array}$ \\
\hline $\begin{array}{l}\text { Subyek } \\
\text { sehat }^{6}\end{array}$ & $300 \mathrm{mg}$ & $\begin{array}{l}\text { TT } \\
\text { TC } \\
\text { CC }\end{array}$ & $\begin{array}{r}.5 \pm 1.7 \\
11.7 \pm 7.9 \\
8.1 \pm 6.9\end{array}$ & $\begin{array}{c}236.6 \\
1641 \pm 61.2 \\
195.7 \pm 136.4\end{array}$ \\
\hline $\begin{array}{l}\text { Pasien } \\
\text { Coronary }\end{array}$ & $300 \mathrm{mg}$ & $\begin{array}{l}\text { TT } \\
\text { TC } \\
\text { CC }\end{array}$ & $\begin{array}{c}11.35 \pm 3.27 \\
33.38 \pm 26.12 \\
38.08 \pm 30.93\end{array}$ & $\begin{array}{l}1.88 \pm 1.03 \\
7.62 \pm 5.82 \\
8.22 \pm 6.07\end{array}$ \\
\hline $\begin{array}{l}\text { artery } \\
\text { disease }^{9}\end{array}$ & $600 \mathrm{M}$ & $\begin{array}{l}\text { TT } \\
\text { TC } \\
\text { CC }\end{array}$ & $\begin{array}{c}25.09 \pm 7.72 \\
120.58 \pm 96.78 \\
109.43 \pm 84.03\end{array}$ & $\begin{array}{c}3.48 \pm 1.65 \\
11.72 \pm 9.20 \\
14.25 \pm 9,53\end{array}$ \\
\hline
\end{tabular}

AUC: Area Under Curve; Data AUC diberikan dalam nilai mean \pm standar deviasi (SD);

$(*)$ : Metabolit aktif klopidogrel yang dievaluasi adalah metabolit thiol 
Tabel 2. Ringkasan riset artikel yang terseleksi

\begin{tabular}{|c|c|c|c|c|}
\hline Subjek/(N) & $\begin{array}{c}\text { Etnis / } \\
\text { negara }\end{array}$ & Dosis klopidogrel & $\begin{array}{c}\text { Profil farmakokinetik pada } \\
\text { gen } M D R-1 \text { varian } 3435\end{array}$ & $\begin{array}{c}\text { Pustaka } \\
\text { nomor }\end{array}$ \\
\hline Subjek sehat/(22) & Korea & $\begin{array}{l}\text { Klopidogrel } 300 \mathrm{mg} \\
\text { (hari pertama) dan } 75 \\
\text { mg sehari sekali } \\
\text { selama } 6 \text { hari } \\
\text { berturut turut }\end{array}$ & $\begin{array}{l}\text { AUC dari klopidogrel dan metabolit } \\
\text { aktifnya adalah } 3435 \mathrm{TT}<3435 \mathrm{CC}< \\
\text { 3435TC (tapi tidak berbeda bermakna) }\end{array}$ & 6 \\
\hline $\begin{array}{l}\text { Subjek } \\
\text { sehat/(160) }\end{array}$ & USA & $\begin{array}{c}\text { Klopidogrel } 75 \\
\text { mg/hari selama } 9 \text { hari }\end{array}$ & $\begin{array}{c}\text { AUC dan konsentrasi maksimum }\left(\mathrm{C}_{\max }\right) \\
\text { klopidrogel metabolit aktif tidak } \\
\text { berkorelasi dengan varian } 3435\end{array}$ & 7 \\
\hline $\begin{array}{l}\text { Pasien Acute } \\
\text { coronary } \\
\text { syndrome } \\
(\mathrm{ACS}) /(401)\end{array}$ & Cina & $\begin{array}{l}\text { Klopidogrel } 300 \mathrm{mg} \\
\text { loading dose }\end{array}$ & $\begin{array}{c}\text { AUC dan } \mathrm{C}_{\max } \text { klopidogrel dan metabolit } \\
\text { (inaktif dan aktif) berkurang secara } \\
\text { signifikan pada } 3435 \mathrm{TT} \text { dan } 3435 \mathrm{TC}, \\
\text { dibandingkan 3435CC }\end{array}$ & 8 \\
\hline $\begin{array}{l}\text { Pasien Coronary } \\
\text { artery disease } \\
(\mathrm{CAD}) /(60)\end{array}$ & Jerman & $\begin{array}{c}\text { Klopidogrel } \\
300 \mathrm{mg}, 600 \mathrm{mg}\end{array}$ & $\begin{array}{c}\text { AUC dan } \mathrm{C}_{\max } \text { klopidogrel dan metabolit } \\
\text { aktifnya berkurang secara signifikan } \\
\text { pada TT, dibandingkan dengan } \\
\text { TC dan CC }\end{array}$ & 9 \\
\hline $\begin{array}{l}\text { Subjek yang akan } \\
\text { menjalani elective } \\
\text { coronary } \\
\text { angiography dan } \\
\text { Percutaneous } \\
\text { Coronary } \\
\text { Intervention } \\
(\mathrm{PCI}) /(38)\end{array}$ & $\begin{array}{l}\text { Kaukasia } \\
\text { (central } \\
\text { Poland) }\end{array}$ & $\begin{array}{l}\text { Klopidogrel } 75 \mathrm{mg} \\
\text { maintenance } \\
\text { dose setidaknya } 7 \text { hari } \\
\text { sebelum tindakan }\end{array}$ & $\begin{array}{l}\text { AUC pada klopidrogel lebih rendah } \\
\text { secara signifikan pada 3435TT } \\
\text { dibandingkan pada } 3435 \mathrm{CC} \text { dan } 3435 \mathrm{TC}\end{array}$ & 10 \\
\hline $\begin{array}{l}\text { Pasien kandidat } \\
\text { untuk } \\
\text { revascularization } \\
\text { dengan } \mathrm{PCI} /(10)\end{array}$ & Italia & $\begin{array}{l}\text { Klopidogrel (single } \\
\text { oral loading dose) } \\
600 \mathrm{mg} \text {, diikuti } 75 \mathrm{mg} \\
\text { per hari }\end{array}$ & $\begin{array}{l}\text { AUC dan } \mathrm{C}_{\max } \text { diukur. Hasilnya adalah } \\
\text { 3435TT genotip menurunkan secara } \\
\text { signifikan absorpsi klopidogrel }\end{array}$ & 11 \\
\hline $\begin{array}{l}\text { Pasien yang } \\
\text { menjalani } \\
\text { coronarography } \\
\text { atau PCI/(22) }\end{array}$ & Kaukasia & $\begin{array}{l}\text { Klopidogrel } 75-\mathrm{mg} \\
\text { setidaknya } 7 \text { hari } \\
\text { Sebelum tindakan }\end{array}$ & $\begin{array}{l}\text { 3435TT genotip adalah kovariat dari } \\
\text { clearance/bioavailabilitas (CL/F), } \\
\text { dengan adanya } 3435 \mathrm{TT} \text { apparent } \\
\text { clearance dari klopidogrel } \\
\text { adalah lebih tinggi }\end{array}$ & 12 \\
\hline $\begin{array}{l}\text { Pasien dengan } \\
\text { coronary artery } \\
\text { disease/(73) }\end{array}$ & $\begin{array}{c}\text { Kaukasia } \\
\text { (mayoritas) }\end{array}$ & $\begin{array}{l}\text { Klopidogrel (single } \\
\text { oral loading dose) } \\
600 \mathrm{mg} \text {, diikuti } \\
75 \mathrm{mg} \text { per hari }\end{array}$ & $\begin{array}{l}\text { Tidak dapat mendeteksi efek dari } \\
\text { ABCB1 genotip, karena } 3435 \mathrm{CC} \\
\text { tidak ditemukan }\end{array}$ & 13 \\
\hline
\end{tabular}


Tabel 3. Hasil penilaian kualitas riset artikel yang terseleksi

\begin{tabular}{|c|c|c|c|c|c|c|c|c|}
\hline Kriteria* & et $_{\text {et }}^{\text {Kim }}$ & $\begin{array}{c}\text { Frelinger } \\
\quad \text { et al }\end{array}$ & $\begin{array}{l}\text { Wang } \\
\text { et al }\end{array}$ & $\begin{array}{c}\text { Taubert } \\
\text { et } a l^{9}\end{array}$ & $\begin{array}{l}\text { Karazniewicz- } \\
\text { lada } \text { et }_{\text {al }}{ }^{10}\end{array}$ & $\begin{array}{l}\text { Danese } \\
\text { et } \text { al }^{11}\end{array}$ & $\begin{array}{c}\text { Danielak } \\
\text { et } a l^{12}\end{array}$ & $\begin{array}{l}\text { Braun } \\
\text { et al }^{13}\end{array}$ \\
\hline 1 & $\mathrm{Y}$ & $\mathrm{Y}$ & $\mathrm{Y}$ & $\mathrm{Y}$ & $\mathrm{Y}$ & $\mathrm{Y}$ & $\mathrm{Y}$ & $\mathrm{Y}$ \\
\hline 2 & Y & $\mathrm{Y}$ & $\mathrm{Y}$ & $\mathrm{Y}$ & $\mathrm{Y}$ & $\mathrm{Y}$ & $\mathrm{Y}$ & $\mathrm{Y}$ \\
\hline 3 & $\mathrm{~N}$ & NR & NR & NR & NR & $\mathrm{Y}$ & $\mathrm{N}$ & NR \\
\hline 4 & $\mathrm{Y}$ & $\mathrm{Y}$ & NR & $\mathrm{Y}$ & $\mathrm{Y}$ & $\mathrm{Y}$ & $\mathrm{Y}$ & $\mathrm{Y}$ \\
\hline 5 & $\mathrm{~N}$ & $\mathrm{~N}$ & $\mathrm{~N}$ & $\mathrm{Y}$ & $\mathrm{N}$ & $\mathrm{N}$ & $\mathrm{N}$ & $\mathrm{N}$ \\
\hline 6 & $\mathrm{Y}$ & Y & Y & $\mathrm{Y}$ & $\mathrm{Y}$ & Y & $\mathrm{Y}$ & Y \\
\hline 7 & Y & Y & $\mathrm{Y}$ & $\mathrm{Y}$ & Y & Y & Y & Y \\
\hline 8 & Y & Y & $\mathrm{Y}$ & $\mathrm{Y}$ & Y & Y & $\mathrm{Y}$ & Y \\
\hline 9 & $\mathrm{Y}$ & $\mathrm{Y}$ & $\mathrm{Y}$ & $\mathrm{Y}$ & $\mathrm{Y}$ & $\mathrm{Y}$ & $\mathrm{CD}$ & $\mathrm{Y}$ \\
\hline 10 & NA & NA & NA & NA & NA & NA & NA & NA \\
\hline 11 & $\mathrm{Y}$ & $\mathrm{Y}$ & $\mathrm{Y}$ & $\mathrm{Y}$ & $\mathrm{Y}$ & $\mathrm{Y}$ & $\mathrm{Y}$ & $\mathrm{CD}$ \\
\hline 12 & NR & NR & NR & NR & NR & NR & NR & $\mathrm{N}$ \\
\hline 13 & $\mathrm{Y}$ & $\mathrm{Y}$ & NR & $\mathrm{Y}$ & $\mathrm{Y}$ & $\mathrm{N}$ & $\mathrm{Y}$ & $\mathrm{Y}$ \\
\hline 14 & $\mathrm{~N}$ & $\mathrm{Y}$ & $\mathrm{N}$ & $\mathrm{N}$ & $\mathrm{N}$ & $\mathrm{N}$ & $\mathrm{N}$ & $\mathrm{N}$ \\
\hline Rating & Cukup & Bagus & Cukup & Cukup & Cukup & Kurang & Cukup & Cukup \\
\hline
\end{tabular}

$\mathrm{Y}=$ Yes $(\mathrm{Ya}), \mathrm{N}=$ No (Tidak), $\mathrm{NR}=$ Not Response (tidak ada respon), NA $=$ Not Applicable (tidak dapat diterapkan), $\mathrm{CD}=$ Cannot be Determined (Tidak dapat ditentukan)

(*)Kualitas metodologi berdasarkan 14 kriteria pada Quality Assessment Tool for Observational Cohort and Cross-Sectional Studies, dari the National Institutes of Health, National Heart, Lung, and Blood Institute, yaitu :

1. Apakah pertanyaan atau tujuan riset dinyatakan secara jelas?

2. Apakah populasi pada penelitian sudah diyatakan secara spesifik dan jelas batasannya?

3. Apakah subjek yang dapat berpartisipasi dalam penelitian tersebut adalah setidaknya $50 \%$ dari populasi ?

4. Apakah keseluruhan subjek diseleksi atau direkrut dari populasi yang sama atau hampir sama (termasuk periode waktu yang sama)? Apakah kriteria inklusi dan eksklusi pada penelitian telah dinyatakan secara spesifik dan diterapkan pada keseluruhan partisipan?

5. Apakah ada justifikasi tentang besar sampel, power description, atau variance and effect estimates?

6. Untuk analisis pada artikel tersebut, apakah exposure of interes telah diukur atau ditentukan sebelum outcome diukur?

7. Apakah waktu pengamatan adalah cukup untuk dapat melihat hubungan exposure dan outcome jika ada?

8. Untuk exposure yang berbeda jumlah atau tingkatannya, apakah dilakukan pengukuran dengan berbagai level yang berbeda dari exposure yang berkaitan dengan outcome (seperti kategori exposure atau exposure diukur dengan variabel continuous)?

9. Apakah pengukuran exposure (sebagai variabel bebas) dinyatakan secara jelas, valid, reliabel, dan dimplementasikan secara konsisten di seluruh partisipan?

10. Apakah exposure dinilai lebih dari satu kali?

11. Apakah pengukuran outcome (sebagai variabel tergantung) dinyatakan secara jelas, valid, reliabel,dan diimplementasikan secara konsisten di seluruh partisipan?

12. Apakah outcome assessors blinded pada status exposure pada partisipan?

13. Apakah subjek yang tidak dapat mengikuti penelitian hingga akhir (loss to follow-up) adalah $20 \%$ atau kurang dari jumlah awal penelitian (baseline)?

14. Apakah potensial confounding variables diukur dan dilakukan adjustment secara statistik terkait impact-nya pada hubungan antara exposure $(s)$ dan outcome $(s)$ ? 


\section{Outcome (efek gen MDR-1 varian 3435 pada parameter farmakokinetik)}

Gen MDR-1 terdapat pada exon 26. Varian genotip yang terdapat pada gen MDR1 posisi 3435 adalah CC, TT, dan TC. ${ }^{1,2,3}$ Tabel 2 menunjukkan bahwa 535 subjek dengan ischemia-related cardio vascular disease (yaitu pasien dengan diagnosis acute coronary syndrome/ACS, coronary artery disease/CAD, dan pasien percutaneous coronary intervention/PCI) yang diperoleh dari 5 artikel riset ${ }^{8,9,10,11,12}$ menunjukkan varian 3435 dari gen $M D R-1$ dapat mengubah farmakokinetik klopidogrel. Sejumlah 513 dari 535 pasien tersebut menunjukkan kadar puncak $\left(\mathrm{C}_{\max }\right)$ dan total area dibawah kurva (AUC) klopidogrel dan/atau metabolit aktifnya, menurun secara signifikan pada 3435TT dibandingkan pada 3435CC. $8,9,10,11$ Dilaporkan pula pada 22 subjek menunjukkan bahwa 3435TT merupakan kovariat dari clearance (CL)/bioavailabilitas (F) klopidogrel; dan nilai apparent clearance klopidogrel lebih tinggi pada subjek dengan polimorfisme tersebut. $^{12}$

Klopidogrel adalah substrat P-gp. Absorpsi, bioavailabilitas, dan eliminasi dari substrat P-gp dapat dipengaruhi dengan adanya induksi atau inhibisi pada ekspresiPgp. ${ }^{1,14}$ Pada sel epitel intestinal, P-gp bertanggung jawab terhadap efluks obat sehingga membatasi drug cellular uptake dan absorpsinya sedangkan pada sel tubuli ginjal dan permukaan kanalikular hepatosit, ekspresi P-gp dapat meningkatkan eliminasi obat. $^{13}$

Adanya varian 3435TT dapat menyebabkan tingginya ekspresi P-gp sehingga dapat mengakibatkan peningkatan intestinal efluks. Peningkatan efluks tersebut dapat menyebabkan nilai AUC klopidogrel dan metabolit aktifnya yang lebih rendah pada pasien coronary artery disease dengan genotip TT dibandingkan pada genotip CC maupun TC (Tabel 1 dan 2). Peningkatan intestinal efluks, dapat membatasi absorbsi klopidogrel, sehingga dapat berimplikasi pada keterbatasan fungsinya sebagai antiplatelet. $^{8,11}$

Tabel 1 dan 2 memperlihatkan hasil riset pada subjek sehat, yaitu efek polimorfisme 3435 pada farmakokinetik klopidogrel yang berbeda dibandingkan hasil yang diperoleh pada pasien dengan ischemia-related cardiovascular disease. Pada 182 subjek sehat (dari 2 artikel riset), menunjukkan bahwa AUC klopidogrel dan/atau metabolit aktifnya adalah lebih rendah pada mutant 3435TT dibandingkan dengan wild type (3435CC), namun perbedaan hasil tersebut tidak bermakna secara signifikan. Nilai $\mathrm{C}_{\max }$ dari metabolit klopidrogel juga tidak berkorelasi dengan polimorfisme tersebut pada subjek sehat. ${ }^{6,7}$

Status penyakit (metastasis kanker, iskemia, infeksi) dapat mengubah fungsi P-gp. ${ }^{15}$ Kondisi iskemia dapat mempengaruhi ekspresi P-gp. Pada kondisi normal, ekspresi P-gp tidak ditemukan pada jantung atau hanya ditemukan pada endothelial cells of arterioles dan kapiler, tapi tidak pada kardiomiosit. $^{16}$ Namun, terjadi overekspresi P-gp pada kardiomiosit yang mengalami hipoksia iskemik akut maupun kronik. ${ }^{15,16}$ Iskemia juga dapat mempengaruhi fungsi P-gp pada otak. Pada studi tentang cilnidipine, dilaporkan bahwa pada otak umumnya cilnidipine diblok oleh P-gp. Tapi pada otak yang iskemik, cilnidipine dapat terdistribusi masuk kedalam otak. ${ }^{15}$ Ekspresi P-gp dapat menurunkan absorpsi obat. ${ }^{14,17}$ Terdapat variasi ekspresi P-gp pada berbagai segmen intestinal manusia. Pada usus kecil, aktivitas P-gp paling tinggi dideteksi pada daerah ileum sentral. ${ }^{15}$ Variasi ekspresi P-gp juga telah ditemukan pada kolon dan lambung manusia. ${ }^{17}$ Penelitian lebih lanjut perlu dilakukan untuk mengidentifikasi efek iskemia dan polimorfisme gen dalam kaitannya dengan farmakokinetik klopidogrel. 


\section{KESIMPULAN}

Pada pasien dengan dengan ischemiarelated cardiovascular disease, AUC, dan $\mathrm{C}_{\max }$ klopidogrel dan/atau metabolit aktifnya lebih rendah secara signifikan pada 3435 TT dibandingkan dengan 3435 CC. Namun pada subjek sehat, adanya varian 3435 dari gen MDR-1 tidak berkorelasi dengan AUC and $\mathrm{C}_{\max }$ klopidogrel dan/atau metabolit aktifnya. Profil farmakokinetik klopidogrel dapat bervariasi dengan adaya varian 3435 dari gen $M D R-1$ dan pada status kesehatan yang berbeda.

\section{DAFTAR RUJUKAN}

1. Brambilia AJL, Tapia. MDRl (ABCB1) polymorphisms: functional effects and clinical implications. Revista de Investigación Clínica. 2013 SeptOct;65(5):445-54

2. Su J, Xu J, Li X, Zhang H, Hu J, Fang R. et al. ABCB1 C3435T polymorphism and response to clopidogrel treatment in coronary artery disease (CAD) patients: a meta-analysis. Plos One. 2012 Oct;7(10):114

3. Calderón-Cruz B, Rodríguez-Galván K, Manzo-Francisco LA, Vargas-Alarcón G, Fragoso JM, Peña-Duque MA, et al. C3435T polymorphism of the ABCB1 gene is associated with poor clopidogrel responsiveness in a Mexican population undergoing percutaneous coronary intervention. Thrombosis Research. 2015 Nov; 136(5):894-8

4. Simon T, Verstuyft C, Mary-Krause M, Quteineh L, Drouet E, Meneveau N. et al. Genetic determinants of response toclopidogrel and cardiovascular events. New England Journal of Medicine. 2009 Jan;360(4):363-75

5. National Heart Lung and Blood Institute. Quality assessment tool for observational cohort and cross-sectional studies. USA: US Department of Health \& Human Services; 2014.

6. Kim HS, Cho DY, Park BM, Bae SK, Yoon YJ, Minkyung $\mathrm{O}$, et al. The Effect of CYP2C19 genotype on the timecourse of platelet aggregation inhibition afterclopidogrel administration. The Journal of Clinical Pharmacology. 2013;54(8):850-
7.

7. Frelinger $\mathrm{AL} 3 \mathrm{rd}$, Bhatt $\mathrm{D}$, Lee $\mathrm{RD}$, Mulford DJ, Wu J, Nudurupati S, Nigam A, et al. A randomized, 2period, crossover design study toassess the effects of dexlansoprazole, lansoprazole, esomeprazole, and omeprazole on the steady-state pharmacokinetics and pharmacodynamics ofclopidogrel in healthy volunteers. Journal of the American College of Cardiology. 2012;59(14):1304-11

8. Wang XQ, Shen CL, Wang BN, Huang $\mathrm{XH}, \mathrm{Hu} \mathrm{ZL}, \mathrm{Li} J$. Genetic polymorphisms of CYP2C192 and ABCB1 C3435T affect the pharmacokinetic and pharmacodynamic responses to clopidogrel in 401 patients with acute coronarysyndrome. Gene. 2012 Mar;558(2):200-7.

9. Taubert D, Von Beckerath N, Grimberg G, Lazar A, Jung N, Goeser T, et al. Impact of P-glycoprotein on clopidogrel absorption. Clinical Pharmacology and Therapeutics. 2006 Nov;80(5):486-501

10. Karazniewicz-Łada M, Danielak D, Rubis B, Burchardt P, Komosa A, Lesiak $\mathrm{M}$, et al. Impact of common $\mathrm{ABCB} 1$ polymorphism on pharmacokinetics and pharmacodynamics of clopidogrel and its metabolites. Journal of Clinical Pharmacy and Therapeutics. 2014 Nov;40(2):226-31

11. Danese E, Fava C, Beltrame F, Tavella $\mathrm{D}$, Calabria S, Benati $\mathrm{M}$, et al. Relationship between pharmacokinetics and pharmacodynamics of clopidogrel in patients undergoing percutaneous coronary intervention: comparison between vasodilator-stimulated phosphoprotein phosphorylation assay and multiple electrode aggregometry. Journal of Thrombosis and Haemostasis. 2016 Feb; 14(2): 282-93.

12. Danielak D, Karaźniewicz-Łada M, Komosa A, Burchardt P, Lesiak M, Kruszyna L. et al. Influence of genetic co-factors on the population pharmacokinetic model for clopidogrel and its active thiol metabolite. European Journal of Clinical Pharmacology. 2017;73(12):1623-32 
13. Braun OÖ, Angiolillo DJ, Ferreiro JL, Jakubowski JA,Winters KJ, Effron M, et al. Enhanced active metabolite generation and platelet inhibition with prasugrel compared to clopidogrel regardless of genotype in thienopyridine metabolic pathways. Thrombosis and Haemostasis. 2013 Dec; 110(6): 1223-31

14. Wessler JD, Grip LT, Mendell J, Giugliano RP. The P-glycoprotein transport system and cardiovascular drugs. Journal of the American College of Cardiology. 2013 Jun;61(25):2495-502

15. Yano K, Tomono T, Ogihara T. Advances in studies of P-glycoprotein and Its expression regulators. Biological \&
Pharmaceutical Bulletin. 2018;41(1): 11-9.

16. Auzmendi J, Merelli A, Girardi E, Orozco-Suarez S, Rocha L, Lazarowski A. Progressive heart P-glycoprotein (Pgp) overexpression after experimental repetitive seizures (ERS) associated with fatal status epilepticus (FSE) Is it related with SUDEP?. Molecular \& Cellular Epilepsy. 2014 Feb;3:1-9

17. Ho GT, Moodie FM, Satsangi J. Multidrug resistance 1 gene (Pglycoprotein 170): animportant determinant in gastro intestinal disease?. Gut. 2003 May;52(5):759-66. 